\title{
Visual Characteristics of Sajarah Banten Manuscript Illustrations
}

\author{
Savitri Putri Ramadina* Yasraf Amir Piliang \\ Nuning Damayanti Adisasmito Pindi Setiawan \\ Faculty of Arts and Design, Bandung Institute of Technology, \\ Jalan Ganesha No. 10, Bandung, Indonesia
}

\begin{abstract}
Banten Sultanate was an Islamic kingdom in the western part of Java island, and one of important international port in the $15^{\text {th }}$ through $19^{\text {th }}$ century. There were different cultures interacted in Banten, such as from the European, Chinese, Indians, and merchant from Muslim-dominant areas such as Middle East. As a cosmopolitan, the illustrations of one of its historical manuscripts, Sajarah Banten KBG 183 would have distinct visual characteristics. This paper would try to find those characteristics by applying compositional analysis to observe their compositional, technological, and productional modalities. Later, semiotic method would be applied to scrutinize the signs used in the visualization of Sajarah Banten illustrations. The result showed that the illustrations characteristically used firm technical lines and minimalistic colors. The story characters were not drawn and only represented by objects alluding to their positions or activities. These visual characteristics were likely influenced by Islamic art aesthetics of aniconism and European technical drawings of $19^{\text {th }}$ century.
\end{abstract}

Keywords: Banten, illustration, manuscript, visual characteristics.

DOI: $10.7176 / \mathrm{ADS} / 89-04$

Publication date: January $31^{\text {st }} 2021$

\section{Introduction}

The Sultanate of Banten was one of the Islamic kingdoms on the western part of Java, founded by Syarif Hidayatullah or Sunan Gunung Jati (1448-1568) and his son Hasanudin. Sunan Gunung Jati was one of Wali Sanga, a group of Islamic preachers who utilized acculturation in visual artifacts as a medium of $d a^{\prime}$ wah (Islamic teaching). The form of acculturation between traditional and Islamic art by the Wali Sanga on the island of Java contains the old Hindu-Buddhist cultural values as well as traditional beliefs and achieved its classical form in the Islamic period. In addition to the Banten Sultanate, Sunan Gunung Jati also related to the Sultanate of Demak in central Java and the Sultanate of Cirebon on the north coast of Java.

Before the emergence of Banten Sultanate, the area belonged to the Hindu-Buddhist Tarumanegara Kingdom and later Sunda Kingdom. The archaeological findings in Banten Girang showed the presence of $10^{\text {th }}$ century Shivaite temple with Hindu iconographies, and several inscriptions written in Javanese (Guillot, 2011). There are also a group of people called Baduy with the indigenous animistic belief of Sunda Wiwitan which still exist in Banten area until present time.

During its reign, the Banten Sultanate was known as an international trading harbor visited by Chinese, Arabic, Indian, and European merchants. This coastal, seafaring cosmopolitan nature combined with the predominance of Islamic principles and Javanese court influence seemingly left no room for traces of the indigenous field-based culture. However, during 1651-1682 Sultan Ageng Tirtayasa campaigned his "food production" policy through developments of inland fields near the border with Batavia, which was the stronghold of Dutch military force (Guillot, 2011). Although this policy was mainly as a deterrent and a way to watch out for the foreign force, it also revived Banten's indigenous field culture.

Banten Sultanate's unique mixtures of both coastal-cosmopolitan and indigenous culture, blanketed by Islamic teachings gave birth to distinct visual characteristics found in one of the manuscripts depicting the history of the sultanate, Sajarah Banten. The name Sajarah Banten ("History of Banten") itself is collectively used to refer to a group of 29 manuscripts detailing the legend and history surrounding the founding, rise and decline of Banten Sultanate from $15^{\text {th }}$ century to $19^{\text {th }}$ century. Among those 29 manuscripts only one of them containing illustrations, which is Sajarah Banten in Indonesian National Library collection coded KBG 183.

The Sajarah Banten KBG 183 manuscript was written in Pegon alphabets, which were Arabic alphabets adapted for Javanese language, with total 87 pages (Pudjiastuti, 2010). The first part of the manuscript told of the founding of Banten Sultanate and the genealogy of Banten rulers traced all the way back to Prophet Muhammad, PBUH, to establish their sovereignty as Islamic kingdom. The next part, also the central story of the manuscript, was the reign of Sultan Ageng Tirtayasa during 1651-1683 and the succession war between him and his son, Sultan Haji. The manuscript described that the Sultan Haji who conspired with Dutch army to take over Banten from Sultan Ageng Tirtayasa was a fake one while the real Sultan Haji was detained in a faraway island. The rest of the manuscript told of the consequences of the succession war, and the next rulers of Banten up to Sultan Ishaq (Muhammad Ishaq Zainulmuttaqin) in 1801.

Based on the text, it is assumed that it was written at the very least at the end of Sultan Ishaq's reign in 1803 
and the subsequent Dutch occupation. The paper used for the manuscript was also produced during the $19^{\text {th }}$ century. This paper thus analyzing Sajarah Banten KBG 183 illustrations to find its visual characteristics, which could provide insight on how the Banten visual culture develop during the era in which this manuscript was written.

\section{Visual Analysis Method}

This research shall be analyzed by using compositional analysis first and later, semiology. The term 'compositional analysis' was used by Gillian Rose (2016) to describe a way to look at an image itself by paying most attention to its compositional, technological, and productional modality. In this phase there were not interpretation yet, only scrutinizing content, form, and how audience experienced the image. Compositional analysis was usually used in conjunction with other visual method(s) since by itself, it only touched the surface of the image without regard to its meaning and socio-cultural aspects.

Compositional analysis first paid attention to the visual elements of an image while also regarding the techniques used and the production method in its creation. Oftentimes, the technological modality of an image such as its medium could affect its impact to the audience. Later, its visual content shall be elaborated to give a more precise description of the image: how the image was placed in a space, how it was structured, what kind of atmosphere or mood it evoked or its 'expressive content', which is the combined effect of subject matter and visual form of an image (Rose, 2016:79). In this research, compositional analysis was used to describe the sample images to find the common visual characteristics of Sajarah Banten manuscript illustrations. The steps were as follows:

1) Description of visual elements such as lines, shapes, colors.

2) The image composition in its relationship with the manuscript's texts and/or other images.

The next step used semiology or semiotic method to further understand the unique characteristics of Sajarah Banten illustrations. Semiology in general is a study of signs and how the meanings of an image were produced through it. According to Ferdinand de Saussure (Rose, 2016:113), a sign consisted of signified, which was a concept or an object; and signifier, which was a sound or image attached to that concept or object. This research adapted the visual semiotic method of Charles Sanders Peirce to analyze the illustrations of Sajarah Banten. Peircean method utilized three levels of sign:

1) Iconic sign: signifier represented the signified through similarity or likeness. For example: the photograph of a person was an iconic sign of the real one. In this research, the iconic signs were scrutinized during the compositional analysis mentioned above.

2) Indexical sign: the relationship between signifier and signified was scrutinized through their sociocultural meanings inherent in the images. In this research, the implication of using certain images shall be analyzed to find the relation between the illustrations and the context of the manuscript itself.

- Symbolic signs: the relationship between signifier and signified based on convention, often arbitrarily. This research analyzed the symbolic signs in the illustrations to further understand how certain images were used in Sajarah Banten manuscript.

\section{Analysis of Visual Characteristics}

The compositional part of Sajarah Banten KBG 183 was mainly confined by its book dimension, which was roughly the size of A5 paper about 20,5 x 16,5 centimeters. The text was written in a grid layout of $16 \times 11,3$ centimeters made with soft pencil usually consisted of 13-15 lines. When a page contained illustration(s), the text layout usually warped around the drawing's outlines, although in some cases there were clear separated grid between the text and the illustrations.

The illustrations used only three ink colors, which were black, purple, and yellow. Black ink was mainly used for the writings and object outlines, although there were some drawings which used purple ink instead. Purple ink was also used for texts signifying a chapter or part change. Yellow ink was mainly used to fill shapes such as decorative elements or flags. In some illustrations where the text layout followed the drawing's outline both text and drawing used the same ink, so presumably both the writer and illustrator were the same person. It was peculiar since usually the writer or scriber and the illustrator of a traditional manuscript were different people, such as in Javanese court manuscripts during the same era in $19^{\text {th }}$ century (Saktimulya, 2016). 


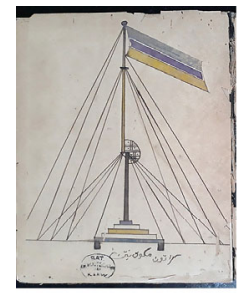

Hal. 01

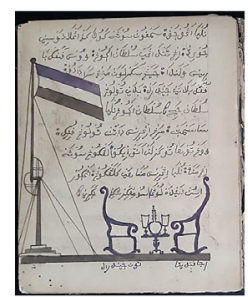

Hal. 31

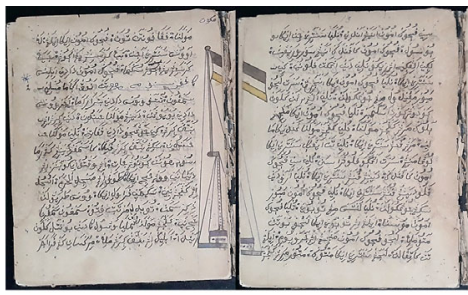

Hal. $12-13$

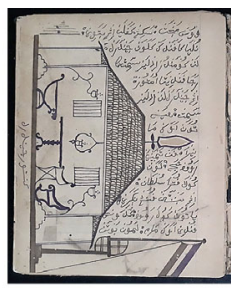

Hal. 27

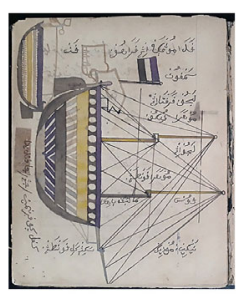

Hal. 37

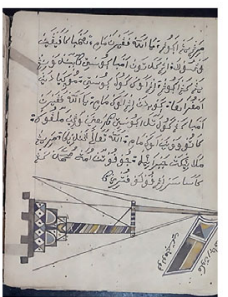

Hal. 62

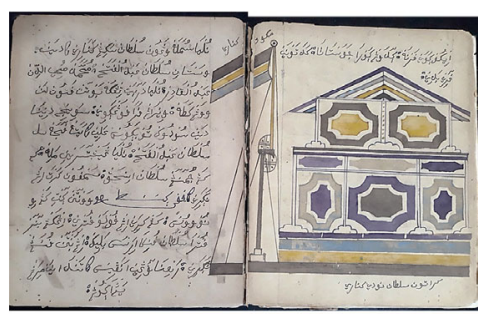

Hal. 61-61a

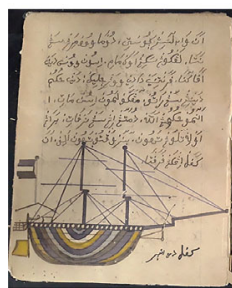

Hal. 71a

Figure 1. Samples of Sajarah Banten KBG 183 illustrations and the corresponding pages

The visual semiotic analysis of Sajarah Banten KBG 183 illustrations thus could be garnered from the compositional analysis. In iconic phase, the illustrations presented objects in semi-realistic manner even though there were no visible usage of perspective, such as the ship illustrations in page 37 and 71a ("hal.37" and "hal.71a" in Figure 1). The lines were crisp and technical. There was no depiction of living beings even though the text alluded to some characters in the story where the corresponding illustrations were placed in the pages.

In indexical phase, the characters' presences were represented by the usage of objects to refer to which personage was implied in the illustration. For example, in page 27 and 31 ("hal.27" and "hal.31" in Figure 1) the text narrated a meeting between Sultan Haji and the Dutch general in Batavia (nowadays Jakarta, Indonesia) to form an alliance to usurp the reigning Sultan Ageng Tirtayasa. The illustration however only depicted two chairs positioned face-to-face with a table between them, and a purple, white, and black-colored flag from top to bottom, presumably alluded to the color value of Dutch flag, which was red, white, and blue. Under each chair was caption on who sat there. For example, in page 31 on the left side under the flag, the caption was tuan jenderal ("sir general"), marking it as where the Dutch general sat. Caption on the right side was raja pandhita ("pious king/lord"), referred to Sultan Haji who just finished his Hajj pilgrimage before coming back to Banten. The caption in page 27 only marked the location, which was kantor jenderal ("General's office"), but the text mentioned the characters which were Sultan Haji and the Dutch general.

In symbolic phase, Sajarah Banten utilized flags to refer to specific places or community. For example, in page 1 ("hal.01" in Figure 1) there was an illustration of greyish/faded black, purple, and yellow colored flag with the caption Keraton Makuwan Banten ("Banten Makuwan Palace") underneath it. The flag symbolized the royal palace of Banten Sultanate without depicting the building in its entirety. In page 12-13 and page 62 ("hal.12-13" and "hal.62" in Figure 1) the captions also referred to places such as makuwan (referring to royal palace) in page 12-13 and Pulo Manjati ("Manjati Island") in page 62. Interestingly, there were also pages where both the flags to symbolizes places and the buildings itself were depicted together, such as the case in page 27 and page 61-61a ("hal.27" and "hal.61-61a" in Figure 1) where the caption was kantor jenderal ("General's office") in page 27 and Keraton Sulthan nuli Kenari ("Sultan's palace in Kenari”) in page 61-61a.

\section{Conclusion}

The illustrations of Sajarah Banten KBG 183 were characterized by minimalist usage of three ink colors, which were black, mainly for text, objects outline, and to substitute for blue color value in Dutch flag illustrations; purple, especially to replace the value of red color for Dutch flag illustrations; and yellow, which provided 
contrasting combination visually with the black and purple. Objects such as chairs and flags were used to indicate characters mentioned in the text with outright depicting them.

The tendency to avoid depiction of living beings in Sajarah Banten likely influenced by the Islamic art aesthetics of aniconism (Al-Faruqi, 2000). In some Islamic teachings, it was preferred not to portray living beings to avoid idolatry. The technical drawing style with firm and even lines such as the ship and building illustrations reminded to scientific illustrations of $19^{\text {th }}$ century, and of Banten position as the international maritime port. Further research would be needed to ascertain these influences in Sajarah Banten manuscript illustrations, and this research could be used as the starting point.

\section{References}

Al-Faruqi, Ismail R. and Lois Lamya Al-Faruqi. (2000): Atlas Budaya Islam. Bandung: Mizan.

Guillot, Claude. (2011): Banten: Sejarah dan Peradaban Abad X-XVII. Jakarta: Kepustakaan Populer Gramedia. Pudjiastuti, Titik. (2010): Sajarah Banten: Suntingan dan Terjemahan Teks KBG 183. Jakarta: Perpustakaan Nasional RI.

Rose, Gillian. (2016): Visual Methodologies. London: SAGE Publications.

Saktimulya, Sri R. (2016): Naskah-naskah Skriptorium Pakualaman: Periode Paku Alam II (1830-1858). Jakarta: Kepustakaan Populer Gramedia. 